\title{
Multidimensionality and Complexity of Role Stress: An Empirical Study of the Public and Private Sector Managers in Kolkata
}

\author{
Sudeshna Basu Mukherjee \\ University of Calcutta, Kolkata, India \\ Email: sudeshnabasumukerjee@gmail.com
}

Received 22 July 2015; accepted 8 August 2015; published 14 August 2015

Copyright (C) 2015 by author and OALib.

This work is licensed under the Creative Commons Attribution International License (CC BY). http://creativecommons.org/licenses/by/4.0/

(c) (i) Open Access

\section{Abstract}

During the past decade, the public and private sector organizations have undergone rapid and striking changes due to emergence of globalization, liberalization and increased competition has given rise to high level of role stress among employees in the both sectors. Role stress is a pattern of reactions that occur when workers are presented with work demands unmatched to their knowledge and skills that challenge their ability to cope. Stress occurs in many different circumstances, but is particularly strong when a person's ability to control demands at work are threatened. Although individual and organizational characteristics play a role in the development of role stress, yet the majority agree that role stress results from the interaction between the worker and the conditions of work. A study was conducted on 200 managers' equiproportinately drawn from 40 public and private sector organizations in Kolkata, using General Information Schedule and Organizational Role Stress Scale [1]. Findings showed that the nature and distribution of Organizational Role Stress Scale Scores revealed dissimilarities among the four sample groups, and moderate level of organizational role stress was the general characteristic feature of the managers. Some components for organizational role stress in organization showed reportable variation with rank position (senior/junior) of the managers.

\section{Keywords}

Globalization, Change, Role Stress, Moderate Stress and Variation

Subject Areas: Sociology

\section{Introduction}

Swelling global competition has gripped the corporate world to face innovative challenges and recognize that

How to cite this paper: Mukherjee, S.B. (2015) Multidimensionality and Complexity of Role Stress: An Empirical Study of the Public and Private Sector Managers in Kolkata. Open Access Library Journal, 2: e1744. 
their own employees can provide them a sustainable competitive advantage. This realization has come up with an amended emphasis on managing of human resources, the driving force behind the survival and accomplishments of any organization. However, in this era of uncertainty, intricacy and change, it is worth giving attention to job stress as it has become an important issue that is gradually becoming a grave problem for employees, employers and the society at large. Originating from workplace, the stress is induced due to roles performed by individuals as employees at workplace have been a critical organizational stressor [2] [3], which is costing the organization dearly [4]. The multidimensionality and intricacy of role stress highlights the importance of reinforcing a systematic exploration of its experiences, cause and consequences for the management.

The term Stress is discussed not only in everyday dialogues but has also become an all pervading feature of people's life in modern world. Dr. Hans Selye said "Without stress, there would be no life" [5]. Stress is everywhere, whether it is in the family, business organization, enterprise, institute or any other social or economic activities. Right from birth till death, an individual is invariably exposed to various stressful situations. The modern world which is said to be a world of achievements is also a world of stress.

Today people are living in the "Age of stress" [6], which according to Schwarzer [7] cannot result from any opportunity/challenge/constraint/demand whatsoever, unless its outcome are perceived to be both essential and uncertain at the same time. Stress is the psychological and physical state that results from when the resources of the individual are not sufficient to cope with the demands and pressure of the situation [8]. Stress can be caused by organizational environment and person specific variables [9]-[11], as well as by scheduled and unscheduled life events that are both desirable and undesirable in the contingent environment, for organizational survival [12]. Researchers and practitioners approach the topic from many different perspectives and orientation, including medical, engineering and sociology [13]-[15].

Work-related stress that has bothered organizational thinkers from the 1980s is now acutely bothering the ever-evolving post-global organizations that have digested considerable change, from the contingent environment, for concomitant necessity of organizational survival. This in turn has created the mushrooming growth of opportunities and expectations. The advancing business organizations have become the domain of hyperactive, hyper-competitive and hyper-expecting personnel, with high levels of competition, technological advancements, amplified work demands, diminishing resources, and transformations in the opportunities and competences of employees consequently giving rise to stress that should be effectively managed [16]. Researchers have focused on the key determinants of stress that refers to the degree of incongruity or incompatibility of expectations associated with an employee's uncertainty about others' expectations making it difficult, for the employees to decide how best to meet and accomplish the tasks concurrently [17] [18]. Thus stress has long been a concern for researchers and practitioners as it has deleterious effects on individuals' mental and physical health, as well as negative effects on organizational outcomes such as low performance, job dissatisfaction, organizational commitment and intention to remain with the organization and efficiency [19]-[22].

Sociologically roles are the positions in a situation that a person occupies in society to discharge certain expected functions. Role theory suggested that human behaviour is guided by expectations held both by the individual and by other people corresponding to different roles individuals perform or enact in their daily lives. The functionalists perceive a role as the set of expectations that society places on individual, unspoken consensus behavior deemed appropriate and others inappropriate, relatively inflexible and more-or-less universally agreed upon. The interactionist definition of role is more fluid and subtle something that is constantly negotiated between individuals. Organization can be defined as a system of roles [23], which are keys to understanding how an individual functions in any system. The absorption of an individual within an organization through a system of roles which establishes the key aspects of an employee's job-related functions, expectations that the employees have of each other and of the jobs they perform within the organization [24]. Stress, originating from the concept of the role of a person [25]-[27] and its interface with the role occupant [28], has been acknowledged as an important concern in organizational settings [29]. One among the many challenges organizations faces is managing role stress that has assumed great importance due to its enfeebling effects on employees and organizations. However, the polygonal phenomenon of role stress requires dissevering the phenomenon from its various aspects and extents, which amounts to an important research objective needed to, make an investigation into the interface between the individuals and the role they experience the phenomenon activating organizational role stress.

Role is thus defined as "the position one holds in an organization having a set of functions to perform in response to the expectations of others and his/her own expectations about the role” [30]. Role stress refers to the 
conflict and tension due to the roles being enacted by a person at any given point of time [31]. Enacted in the context of organizations, such roles are perceived as a system of different positions or offices in the organization. According to [23], office is a relational or power related concept concerned with the hierarchical positions and privileges, whereas role refers to the obligations attached to that office. Thus, office defines the power of the holder [32], while role determines the obligation of the person holding that office. Pestonjee and Pareek [33] explained role as the totality of formal tasks, informal tasks and acts as organized by an individual.

\section{Concept of Organizational Role Stress (ORS)}

Role is the position occupied by a person as defined by the expectation of the other. Each role is a system of functions and there are two important aspects of an individual's role that should be considered when examining role stress: 1) Role set, which is the role system in an organization that defines individual roles; 2) Role space, which is the roles people occupy and perform. In an organisational context, role behaviours are the recurring patterns of actions that are considered important for effective functioning in that particular role and in that particular organisation (Biddle, 1986). In performance of that role, there are inherent problems due to which stress is inevitable. This study has used Pareek's [1] scale, which evaluates respondents' quantum of stress in terms of total ORS scores. It also measures the intensity of the following ten role stressors that contribute to the total ORS score:

1. Inter-role distance (IRD): Stress is experienced when there is conflict between organizational and non-organizational roles, for example, the role of a manager versus the role of a husband.

2. Role stagnation (RS): The feeling of being "stuck" in the same role.

3. Role expectation conflict (REC): Conflicting expectations and demands between different role senders, i.e., superiors, subordinates, and peers in the organization.

4. Role erosion (RE): The feeling that functions that should belong to the respondent's role are being transformed/performed or shared by others, i.e. when a role has become less important than it used to be, or when the credibility is being shared in the role.

5. Role overload (RO): The feeling that more is expected from the role than the respondent can cope with.

6. Role isolation (RI): Lack of linkages between the respondent's role and that of other roles in the organization.

7. Personal inadequacy (PI): Inadequate knowledge, skills, or preparation for a respondent to be effective in a particular role.

8. Self-role distance (SRD): Conflict between the respondent's values/self-concepts and the requirements of his or her organizational role.

9. Role ambiguity (RA): Lack of clarity about others' expectations of the respondent's role, or lack of feedback on how others perceive the respondent's performance.

10. Resource inadequacy (RIN): Nonavailability of resources needed for effective role performance.

Contextually, in a fast-evolving organizational world, stress arising out of technological advancement is globally obliging managers to work under increased pace of managing and handling multitasks pertaining to a technological innovation (new technical artifacts, devices or products), process innovation (new services, programs, products or procedures) or an administrative innovation (new institutional policies, structures or systems), and this is creating new and increased work pressure [34]. This type of deviation from the normal functioning or lack of fit arising out of the interaction of people and their jobs is termed as role stress. An increased risk of role stress due to work overload, pace of work, inter-role conflicts, work-family imbalance and lack of time for rest and recovery [35], can be defined as characteristic of the job environment which make demands on (tax or exceed) the abilities or resources of the people for meeting the demands or which may otherwise threaten attainment of people's need [36] [37]. Role stressors can influence the perceived well-being, job satisfaction, and overall satisfaction, thus affecting their efficiency and skill. Role stress reduces the feeling of well-being and makes one derive less pleasure from work [38]. Organizational role stress is significantly but negatively correlated with personal adjustment and social relations [39].

In view of the above, this study aims to ascertain the influence of various determinants of role stress. The next section reviews the literature followed by the methodology adopted. The ensuing sections discuss the results followed by the conclusion and implications emanating from the study.

While literature illustrates that Kahn, Wolfe, Quinn, Snoek, and Rosenthal [2], were the first to describe orga- 
nizational stress in general and role stress in particular. Role stress, as originally theorized by Katz and Kahn [23], resulted from an employee's role conflict and role ambiguity. Cox [40] asserted that job strain did not necessarily result from the source of the pressure but rather from the employee's perception of the pressure. Further, the ambiguity that arises from being uncertain can also reduce job satisfaction [41]. This suggested that the same event (e.g., workload) might be perceived as highly stressful by some and not stressful by others, that was elements of the objective work environment were evaluated by employees through an appraisal process, which then resulted in a physiological, psychological, or behavioural response [42].

However, role ambiguity and role conflict [43] [44], the absence of transparency and predictableness in the role [45], resource inadequacy [28], role overload, etc. [44] [46], have been linked to role stress. Role stress caused by demands has been found to impact employee performance, attitude, job satisfaction, organizational commitment, etc. [47]-[51]. Role conflict and role ambiguity adversely influence job satisfaction [52], and the latter may also affect the intention to quit one's job [53]. Role stress also leads to psychological strain which occurs when organizational stress leads to ineffective cognitive functioning [54]-[56].

Linzer et al. [57] assessed predictors of stress among US physicians and found that job demand, work hours, time pressure, and less control of workplace hassles, lack of support by colleagues for balancing work and home worsened by work demands were the major predictors of stress [58] [59]. The study of Boles et al. [60] found that role conflict, role ambiguity, and work-family conflict impacted overall job satisfaction. A study conducted by LeRouge et al. [61] concluded that role stress was positively related to both job satisfaction and organizational commitment and that self-esteem significantly moderated the relationship between role stresses, fit and job satisfaction. Mulki et al. [62] investigated the effect of work overload and self-efficacy on important job outcomes, capability rewards and pay satisfaction. As stated by Verma [63], that occupational role stress was found to be significantly related to job satisfaction; while Cuhadar [64] observed significant difference in the level of role conflict and role ambiguity of public sector and private sector managers. Ahsan et al. [65] investigated the relationship between job stress and job satisfaction. The determinants of job stress that have been examined under this study include, management role, relationship with others, workload pressure, homework interface, role ambiguity, and performance pressure and found significant negative relationship between job stress and job satisfaction. Sankpal et al. [66] compared organizational role stress of managers in public and private banks of Gwalior. Significant difference in certain aspects like Self role distance, Inter-role distance, Role-stagnation, Role overload, Role erosion and Resource inadequacy had been observed. According to Correa and Ferreira [7], occupational stress such as role conflict, work overload, interpersonal difficulties, work-family conflict, work instability, lack autonomy and pressure of responsibility showed that the role conflict and work overload had a negative impact on job satisfaction. Bano and Jha [67] in a survey explored the differences in job-related stress, between public and private sector employees, based on ten role stressors; they reported that both public and private sector employees face moderate levels of stress. While there was no significant difference overall between public and private sector employees in terms of total stress levels, certain individual stressors-such as work experience and educational qualifications did yield difference. Christiana $\mathrm{M}$ and Mahalakshmi [68] attempted to identify the differences in job-related stress pertaining to the managers in both public and private sector, made it quite evident that though there was no significant difference in the stress experienced by both certain individual stressors such as work experience and educational qualifications yield differences. Khanna [69] studied the ORS and life satisfaction among female doctors in a sample of 40 female doctors, outcomes indicated that higher the life satisfaction lower would be the total organizational role stress.

However, studies suggested that role stress may result from an intricate interaction between personal characteristics and the work environment [70]-[74]. The personal characteristics are a part of what an individual brings to the workplace. Clayson and Frost [75], and Chandriah et al. [76] established a relationship between age and stress while Saravanan and Lawrence [77] identified its relationship with a number of economically dependents in the family and the amount of salary an individual receives. Fried et al. [78] indicated that role stress was related to job performance both directly and indirectly through job satisfaction and propensity to leave. Shahu and Gole [47] found that higher stress level was related to lower performance and Anton [79], identified role ambiguity as the critical predictor of workers' performance and job satisfaction. Moreover, the sector which the organization belongs to can also be one of the determinants of role stress for employees [66] [80].

Role stress is a multidimensional complex phenomenon [6], the understanding of which is critical for warranting the welfare of employees and functioning of organizations [79] [81]. It may be difficult to attribute role stress exclusively to organizations as personalities play a key part in determining the phenomenon [82]. This 
makes it important to examine the dynamism of role stress at workplace. A review of the existing literature suggested that a variety of organizational and personal factors were linked to role stress. There is dearth of comprehensive studies which assess the experience of role stress, not only its aspects but also its various determinants, particularly in India and more specifically in Kolkata. With this backdrop in mind, the present study had been undertaken with the following objectives:

- to explore the differences in job-related stress, if any, between public and private sector mangers, based on ten role stressors.

- to study the differences in the nature of role stress variables with respect to rank position (senior and junior) of the managers in public and private sector organizations.

\section{Area of Study: Public and Private Sector Organizations:}

Public Sector organizations are a consortium of organizations that have governmental governance (controlled fully/partially by the government), an undertaking where the government rules and policies impinge upon organizational rules of governance, joint venture organizations where the government of a state or the central government jointly float a company with shares holding that govern policy making and investments.

Private Sector organizations are those, private limited companies of Indian origin, Multinational corporations (MNC's) and other related organizations that have operations in various countries. These organizations are governed by rules and policies formulated according to certain guidelines of the state and central government.

During the past decade, the organizations in India had undergone rapid and striking changes due to emergence of globalization, liberalization and increased competition. That is why the employees are experiencing a high level of stress. Our focus, however, is on Organizational Role Stress (ORS), which measures total role stress.

\section{Method}

\subsection{Respondents}

Managers working in these organizations, include all those who fall in the managerial cadre according to book rules of the concerned organization as designations differed from organization to organizations.

\subsection{Sample}

1) Forty organizations (20 public and 20 private) were selected on the basis of the criteria that a) they fulfilled the ISO standards; b) they have had a de-layering/downsizing exercise after the 1991 liberation policy (restructuring of the organization); c) they followed at least two among the following procedural systems: Competency mapping/performance appraisal, business balance scorecard, benchmarking, Kaizen (continuous improvement). 2) Altogether, 200 managers' equiproportinately drawn from public and private organizations. The sample was also equiproportinately drawn with regard to ranks/ positions (senior or junior) according to designations as per organizational allotments through purposive sampling based on the inclusion criteria of age range (30 - 40 years) and number of years of service ( 5 - 10 years).

\subsection{Data Collection}

Responses of 200 managers of private- and public-sector organizations were collected and considered through the General Information Schedule and Organizational Role Stress Scale [1].

\subsection{Statistical Methods}

Mean, standard deviation, and ANOVA were calculated on the basis of the scores of the abovementioned inventories and scale.

\subsection{Ethical Consideration}

In data collection, negotiation has been made with the organizations and respondents to gain permission in order to conduct interviews. Respondents were informed the purpose of the study. Anonymity was maintained and the data was handled with confidentiality. 


\section{Interpretation of Organizational Role Stress Scale (ORS) Scores}

Considering the objectives of the study, the analyses of results of ORS were concentrated on two areas:

a) Analysis of the trend and distribution pattern of Organizational Role Stress Scale Scores.

b) Comparative status of Organizational Role Stress Scale Scores of managers both Public and Private sector Organizations.

\subsection{Trends of Organizational Role Stress Scale Scores}

In order to achieve the objective the total scores of ORS scale with its components-were analyzed and presented in the following table. In order to test the sample characteristics, as well as the nature of tests scores, central tendencies and dispersion were calculated for total scores and has been presented in the following sub-section and (Table 1 and Table 2).

The values displayed in the Table 1 characterize four groups of managers with apparent notional differences; have been revealed a statistical similarity among the groups (4) with references to probable normal distribution of score trends, with slight variation in their respective skewness and kurtosis (Figure 1).

The chi-square test was compiled to measure the nature of divergence from the normal distribution and result revealed the following $\mathrm{X}^{2}$ value viz.

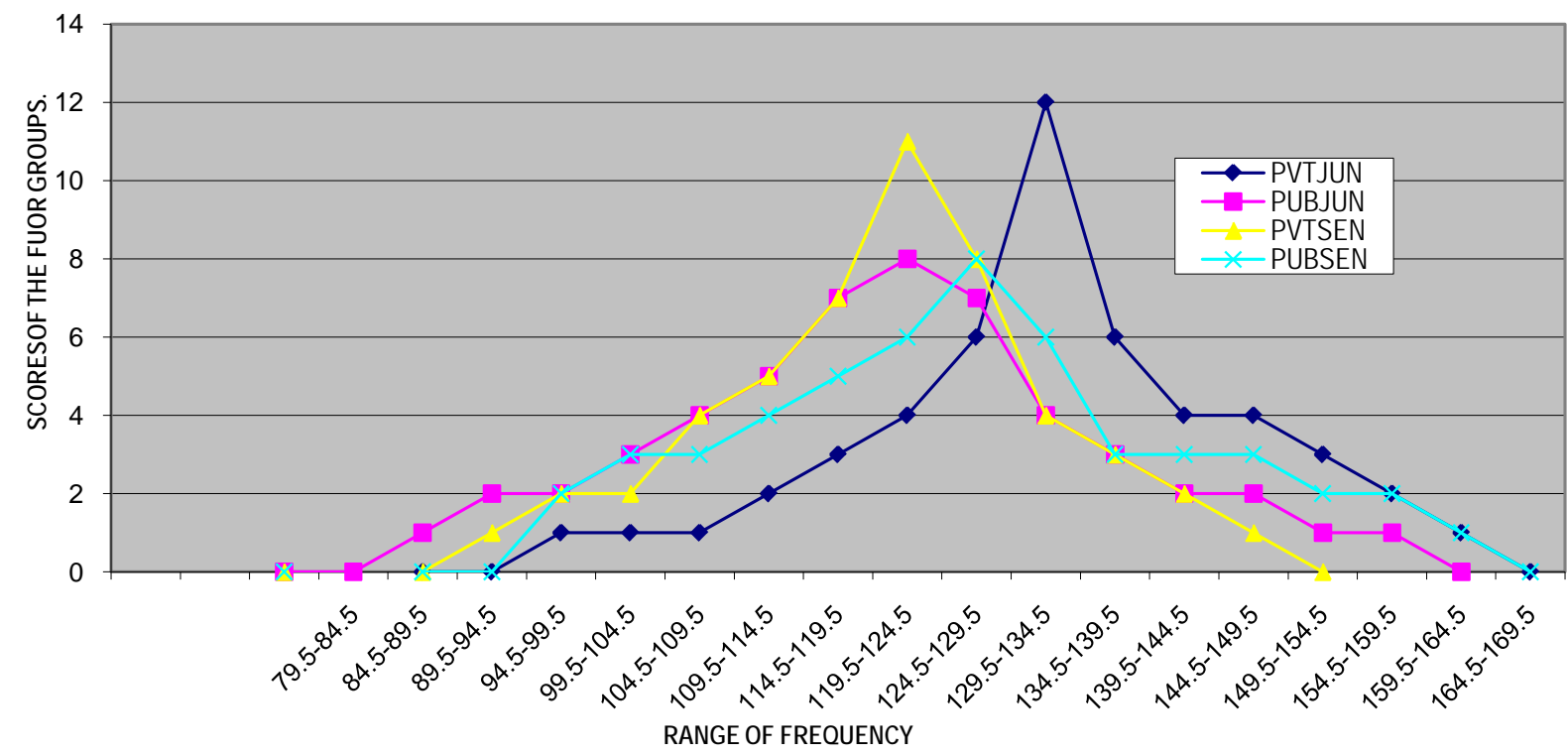

Figure 1. Frequency polygon of organizational role stress scale scores of four sample groups.

Table 1. Indicating the central tendencies and standard deviation of the tests scores in a four sample groups (Number of informants 200 managers both from private and public sector organizations).

\begin{tabular}{|c|c|c|c|c|c|c|c|}
\hline \multirow{2}{*}{$\begin{array}{c}\text { Name } \\
\text { of Scores }\end{array}$} & \multirow{2}{*}{$\begin{array}{c}\text { Total Sample } \\
\text { Scores }\end{array}$} & \multicolumn{3}{|c|}{ Public Sector Managers } & \multicolumn{3}{|c|}{ Private Sector Managers } \\
\hline & & Junior & Senior & Combined & Junior & Senior & Combined \\
\hline Mean & 122.48 & 112.28 & 130.40 & 121.34 & 131.92 & 115.32 & 123.62 \\
\hline Median & 126.00 & 114.00 & 135.50 & 121.00 & 131.00 & 119.50 & 127.50 \\
\hline Mode & 130.00 & 118.00 & 146.00 & 120.00 & 130.00 & 118.00 & 130.00 \\
\hline SD & 19.78 & 18.35 & 22.87 & 22.55 & 13.13 & 15.64 & 16.61 \\
\hline Skewness & -0.142 & -0.202 & -0.361 & -0.013 & -0.320 & -0.006 & -0.277 \\
\hline Kurtosis & -0.603 & 0.025 & -1.264 & -0.815 & 0.977 & -1.606 & -0.654 \\
\hline
\end{tabular}


Table 2. Distribution of Mean (M), Standard Deviation (SD) and Standard Score (SS) of Organizational Role Stress Scale (ORS) Scores of the four sample groups of managers (50 junior and 50 senior group) private sector managers and (50 junior and 50 senior group) public sector organizations.

\begin{tabular}{|c|c|c|c|c|c|c|c|}
\hline \multirow{3}{*}{ Enquiry Area } & \multicolumn{7}{|c|}{ Mean (M), Standard Deviation (SD) and Standard Scores (SS) of ORS Scale within: } \\
\hline & \multicolumn{2}{|c|}{ Private Sector Managers } & \multicolumn{2}{|c|}{ Public Sector Managers } & \multirow{2}{*}{$\begin{array}{l}\text { Private Sector } \\
\text { Managers } \\
\text { Junior }+ \\
\text { Senior } 100\end{array}$} & \multirow{2}{*}{$\begin{array}{c}\text { Public Sector } \\
\text { Managers } \\
\text { Junior+ }+ \\
\text { Senior } 100\end{array}$} & \multirow{2}{*}{$\begin{array}{c}\text { Private and } \\
\text { Public Sector } \\
\text { Total }=200\end{array}$} \\
\hline & $\begin{array}{c}\text { Junior } \\
\text { Group } \\
50\end{array}$ & $\begin{array}{l}\text { Senior } \\
\text { Group } \\
50\end{array}$ & $\begin{array}{l}\text { Junior } \\
\text { Group } \\
50\end{array}$ & $\begin{array}{l}\text { Senior } \\
\text { Group } \\
50\end{array}$ & & & \\
\hline $\begin{array}{l}\text { Inter Role } \\
\text { Distance } \\
\text { (IRD) }\end{array}$ & $\begin{array}{c}\mathrm{M}=11.18 \\
\mathrm{SD}=4.03 \\
\mathrm{SS}=102.16\end{array}$ & $\begin{array}{c}\mathrm{M}=9.02 \\
\mathrm{SD}=3.87 \\
\mathrm{SS}=92.61\end{array}$ & $\begin{array}{c}M=11.10 \\
\mathrm{SD}=4.42 \\
\mathrm{SS}=101.81\end{array}$ & $\begin{array}{l}M=11.40 \\
S D=5.22 \\
S S=97.39\end{array}$ & $\begin{array}{l}M=10.10 \\
S D=4.08 \\
S S=97.43\end{array}$ & $\begin{array}{c}\mathrm{M}=11.25 \\
\mathrm{SD}=4.81 \\
\mathrm{SS}=102.51\end{array}$ & $\begin{array}{l}M=10.69 \\
S D=4.52\end{array}$ \\
\hline $\begin{array}{l}\text { Role } \\
\text { Stagnation } \\
\text { (RS) }\end{array}$ & $\begin{array}{c}M=12.76 \\
S D=2.98 \\
S S=105.22\end{array}$ & $\begin{array}{l}M=11.28 \\
S D=3.09 \\
S S=96.12\end{array}$ & $\begin{array}{c}M=12.02 \\
S D=3.59 \\
S S=100.67\end{array}$ & $\begin{array}{l}M=11.58 \\
S D=3.21 \\
S S=97.97\end{array}$ & $\begin{array}{c}M=12.02 \\
S D=3.11 \\
S S=100.67\end{array}$ & $\begin{array}{l}M=11.80 \\
S D=3.39 \\
S S=99.32\end{array}$ & $\begin{array}{l}M=11.91 \\
S D=3.25\end{array}$ \\
\hline $\begin{array}{c}\text { Role } \\
\text { Expectation } \\
\text { Conflict (REC) }\end{array}$ & $\begin{array}{l}M=11.66 \\
S D=2.66 \\
S S=94.95\end{array}$ & $\begin{array}{l}M=11.38 \\
S D=4.09 \\
S S=93.20\end{array}$ & $\begin{array}{c}M=13.44 \\
S D=3.73 \\
S S=106.05\end{array}$ & $\begin{array}{c}M=13.40 \\
\mathrm{SD}=4.16 \\
\mathrm{SS}=105.80\end{array}$ & $\begin{array}{l}M=11.52 \\
S D=3.43 \\
S S=94.07\end{array}$ & $\begin{array}{c}M=13.42 \\
S D=3.93 \\
S S=105.93\end{array}$ & $\begin{array}{l}M=12.47 \\
S D=3.81\end{array}$ \\
\hline $\begin{array}{c}\text { Role } \\
\text { Erosion (RE) }\end{array}$ & $\begin{array}{c}M=13.20 \\
S D=2.91 \\
S S=104.76\end{array}$ & $\begin{array}{c}\mathrm{M}=14.10 \\
\mathrm{SD}=2.88 \\
\mathrm{SS}=110.17\end{array}$ & $\begin{array}{l}\mathrm{M}=11.42 \\
\mathrm{SD}=3.75 \\
\mathrm{SS}=94.04\end{array}$ & $\begin{array}{c}\mathrm{M}=12.88 \\
\mathrm{SD}=3.36 \\
\mathrm{SS}=102.83\end{array}$ & $\begin{array}{c}\mathrm{M}=12.67 \\
\mathrm{SD}=3.01 \\
\mathrm{SS}=101.20\end{array}$ & $\begin{array}{l}M=12.15 \\
S D=3.61 \\
S S=98.43\end{array}$ & $\begin{array}{l}\mathrm{M}=12.41 \\
\mathrm{SD}=3.32\end{array}$ \\
\hline $\begin{array}{c}\text { Role } \\
\text { Overload (RO) }\end{array}$ & $\begin{array}{c}M=17.52 \\
S D=1.75 \\
S S=139.32\end{array}$ & $\begin{array}{l}\mathrm{M}=10.82 \\
\mathrm{SD}=2.88 \\
\mathrm{SS}=94.97\end{array}$ & $\begin{array}{c}\mathrm{M}=14.88 \\
\mathrm{SD}=2.22 \\
\mathrm{SS}=121.85\end{array}$ & $\begin{array}{c}\mathrm{M}=15.50 \\
\mathrm{SD}=2.84 \\
\mathrm{SS}=125.95\end{array}$ & $\begin{array}{c}\mathrm{M}=16.73 \\
\mathrm{SD}=2.66 \\
\mathrm{SS}=134.09\end{array}$ & $\begin{array}{c}\mathrm{M}=15.19 \\
\mathrm{SD}=2.56 \\
\mathrm{SS}=123.89\end{array}$ & $\begin{array}{l}M=11.58 \\
S D=3.02\end{array}$ \\
\hline $\begin{array}{c}\text { Role } \\
\text { Isolation (RI) }\end{array}$ & $\begin{array}{c}M=11.30 \\
S D=3.21 \\
S S=104.08\end{array}$ & $\begin{array}{c}\mathrm{M}=9.00 \\
\mathrm{SD}=3.28 \\
\mathrm{SS}=91.55\end{array}$ & $\begin{array}{c}\mathrm{M}=9.22 \\
\mathrm{SD}=3.66 \\
\mathrm{SS}=92.75\end{array}$ & $\begin{array}{c}M=12.68 \\
\mathrm{SD}=3.30 \\
\mathrm{SS}=101.61\end{array}$ & $\begin{array}{l}M=10.15 \\
S D=3.43 \\
S S=97.82\end{array}$ & $\begin{array}{c}\mathrm{M}=10.95 \\
\mathrm{SD}=3.88 \\
\mathrm{SS}=102.18\end{array}$ & $\begin{array}{l}M=10.55 \\
S D=3.67\end{array}$ \\
\hline $\begin{array}{l}\text { Personal } \\
\text { Inadequacy } \\
\text { (PI) }\end{array}$ & $\begin{array}{c}M=12.96 \\
S D=3.64 \\
S S=105.33\end{array}$ & $\begin{array}{c}\mathrm{M}=12.50 \\
\mathrm{SD}=4.21 \\
\mathrm{SS}=102.94\end{array}$ & $\begin{array}{c}\mathrm{M}=9.82 \\
\mathrm{SD}=3.37 \\
\mathrm{SS}=89.09\end{array}$ & $\begin{array}{c}M=12.44 \\
S D=3.54 \\
S S=102.64\end{array}$ & $\begin{array}{c}M=12.73 \\
S D=3.92 \\
S S=104.29\end{array}$ & $\begin{array}{l}M=11.13 \\
S D=3.68 \\
S S=95.86\end{array}$ & $\begin{array}{l}M=11.93 \\
S D=3.87\end{array}$ \\
\hline $\begin{array}{l}\text { Self Role } \\
\text { Distance } \\
\text { (SRD) }\end{array}$ & $\begin{array}{c}M=17.66 \\
S D=1.88 \\
S S=129.18\end{array}$ & $\begin{array}{c}M=15.80 \\
S D=2.82 \\
S S=135.04\end{array}$ & $\begin{array}{c}M=14.94 \\
S D=3.19 \\
S S=115.24\end{array}$ & $\begin{array}{c}M=15.90 \\
S D=3.59 \\
S S=120.16\end{array}$ & $\begin{array}{c}M=16.62 \\
S D=2.60 \\
S S=123.85\end{array}$ & $\begin{array}{c}M=15.42 \\
S D=3.42 \\
S S=110.87\end{array}$ & $\begin{array}{l}M=11.97 \\
S D=3.90\end{array}$ \\
\hline $\begin{array}{l}\text { Role } \\
\text { Ambiguity } \\
\text { (RA) }\end{array}$ & $\begin{array}{c}M=12.38 \\
S D=3.04 \\
S S=109.34\end{array}$ & $\begin{array}{c}M=9.64 \\
S D=3.26 \\
S S=95.50\end{array}$ & $\begin{array}{c}\mathrm{M}=7.84 \\
\mathrm{SD}=3.84 \\
\mathrm{SS}=84.42\end{array}$ & $\begin{array}{c}\mathrm{M}=12.24 \\
\mathrm{SD}=3.83 \\
\mathrm{SS}=108.63\end{array}$ & $\begin{array}{c}\mathrm{M}=11.90 \\
\mathrm{SD}=3.53 \\
\mathrm{SS}=106.92\end{array}$ & $\begin{array}{l}M=10.04 \\
S D=4.39 \\
S S=97.52\end{array}$ & $\begin{array}{l}M=10.53 \\
S D=3.96\end{array}$ \\
\hline $\begin{array}{l}\text { Resource } \\
\text { Inadequacy } \\
\text { (RIN) }\end{array}$ & $\begin{array}{c}M=11.34 \\
S D=3.02 \\
S S=106.70\end{array}$ & $\begin{array}{c}\mathrm{M}=9.68 \\
\mathrm{SD}=2.92 \\
\mathrm{SS}=96.49\end{array}$ & $\begin{array}{c}\mathrm{M}=7.60 \\
\mathrm{SD}=3.77 \\
\mathrm{SS}=83.70\end{array}$ & $\begin{array}{c}\mathrm{M}=12.38 \\
\mathrm{SD}=4.11 \\
\mathrm{SS}=113.09\end{array}$ & $\begin{array}{c}\mathrm{M}=10.51 \\
\mathrm{SD}=3.08 \\
\mathrm{SS}=101.59\end{array}$ & $\begin{array}{c}\mathrm{M}=9.99 \\
\mathrm{SD}=4.60 \\
\mathrm{SS}=98.40\end{array}$ & $\begin{array}{l}M=10.25 \\
\mathrm{SD}=3.91\end{array}$ \\
\hline
\end{tabular}

$\begin{array}{ll}\text { Groups } & \mathrm{X}^{2} \\ \text { Public Junior } & 9.31 \\ \text { Public Senior } & 13.24 \\ \text { Private Junior } & 7.36 \\ \text { Private Senior } & 5.71\end{array}$

None of the values $\mathrm{X}^{2}$ earned a statistically high significance indicating their respective closeness towards normal distribution. Figure 2 indicating the frequency polygon of the organizational role stress scale scores.

To highlight the relative weight age and variation of influence of the different components of Organizational Role Stress Scale in the different groups of managers, the mean values (of all components) given in the (Table 2), were taken out and arranged in order of the relative influence or weightage which has been presented in (Table 3).

It has been observed from Table 3 that the level and characteristic features of the component enquiry areas of organizational role stress scale scores have reflected dissimilarities in terms of their relative weightage among different groups. Considering the serial number of rank position (1 to 5) of weightage of enquiry areas for their influence for organizational role stress, the results (Table 3) indicated that the component wise relative influ- 


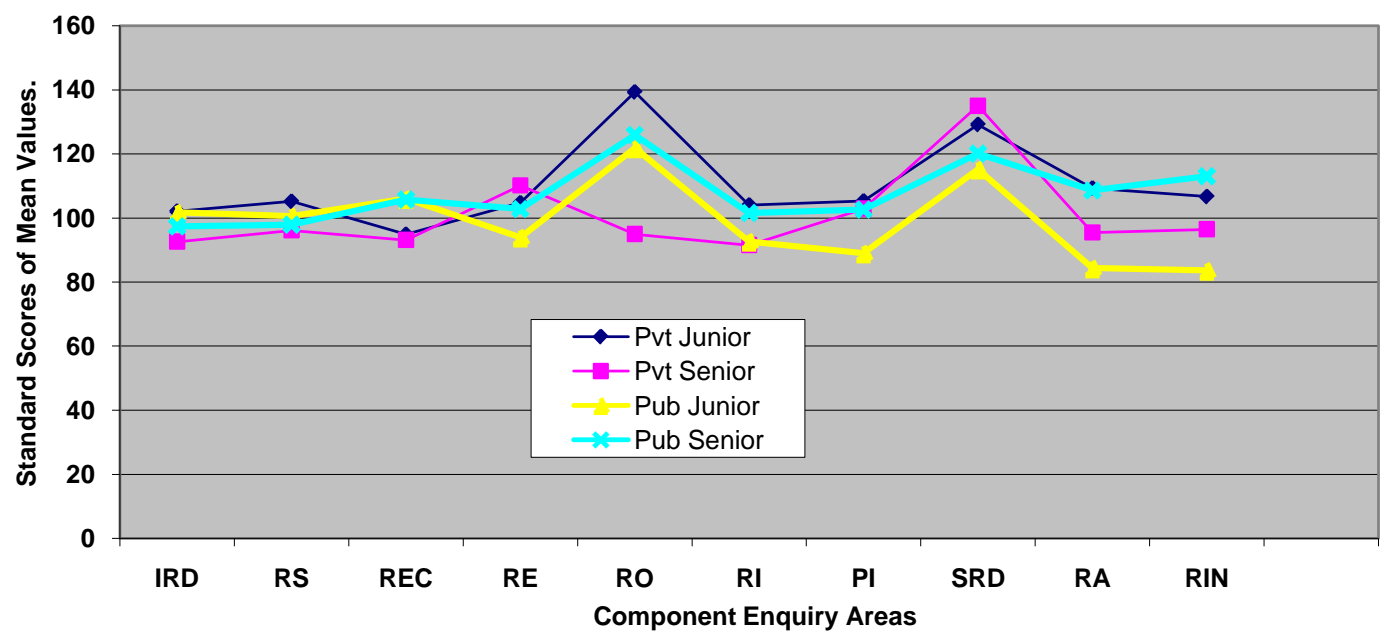

Figure 2. Profile of organizational role stress scale scores for four groups of managers (public and private) both (high and low) stressed in Terms of their standard scores of mean values of different enquiry areas.

Table 3. The mean of individual enquiry aeas of Organizational Role Stress Scale and their order of relative weightage among the sample groups.

\begin{tabular}{|c|c|c|c|c|c|c|c|c|c|c|c|c|}
\hline \multirow{4}{*}{$\begin{array}{c}\text { Enquiry Areas } \\
\text { of Role } \\
\text { Stress Scale }\end{array}$} & \multicolumn{12}{|c|}{ Mean of Sample Group } \\
\hline & \multicolumn{6}{|c|}{ Public Sector Managers } & \multicolumn{6}{|c|}{ Private Sector Managers } \\
\hline & \multicolumn{2}{|c|}{ Junior } & \multicolumn{2}{|c|}{ Senior } & \multicolumn{2}{|c|}{ Overall } & \multicolumn{2}{|c|}{ Junior } & \multicolumn{2}{|c|}{ Senior } & \multicolumn{2}{|c|}{ Overall } \\
\hline & Mean & Rank & Mean & Rank & Mean & Rank & Mean & Rank & Mean & Rank & Mean & Rank \\
\hline $\begin{array}{c}\text { Inter Role } \\
\text { Distance (IRD) }\end{array}$ & 11.10 & 6 & 11.40 & 10 & 11.25 & 7 & 11.18 & 10 & 9.02 & 9 & 10.10 & 10 \\
\hline $\begin{array}{c}\text { Role } \\
\text { Stagnation (RS) }\end{array}$ & 12.02 & 4 & 11.58 & 9 & 11.80 & 6 & 12.76 & 5 & 11.28 & 6 & 12.02 & 5 \\
\hline $\begin{array}{l}\text { Role Expectation } \\
\text { Conflict (REC) }\end{array}$ & 13.44 & 3 & 13.40 & 3 & 13.42 & 3 & 11.66 & 7 & 11.38 & 5 & 11.52 & 6 \\
\hline $\begin{array}{c}\text { Role } \\
\text { Erosion (RE) }\end{array}$ & 11.42 & 5 & 12.88 & 4 & 12.15 & 5 & 13.20 & 3 & 12.14 & 4 & 12.67 & 4 \\
\hline $\begin{array}{c}\text { Role } \\
\text { Overload (RO) }\end{array}$ & 14.88 & 2 & 15.50 & 2 & 15.19 & 2 & 17.52 & 2 & 15.10 & 2 & 16.31 & 2 \\
\hline $\begin{array}{c}\text { Role } \\
\text { Isolation (RI) }\end{array}$ & 9.22 & 8 & 12.68 & 5 & 10.95 & 8 & 11.30 & 9 & 9.00 & 10 & 10.15 & 9 \\
\hline $\begin{array}{c}\text { Personal } \\
\text { Inadequacy (PI) }\end{array}$ & 9.82 & 7 & 12.44 & 6 & 13.11 & 4 & 12.96 & 4 & 12.50 & 3 & 12.73 & 3 \\
\hline $\begin{array}{c}\text { Self-Role } \\
\text { Distance (SRD) }\end{array}$ & 14.94 & 1 & 15.90 & 1 & 15.42 & 1 & 17.66 & 1 & 15.58 & 1 & 16.62 & 1 \\
\hline $\begin{array}{c}\text { Role } \\
\text { Ambiguity (RA) }\end{array}$ & 7.84 & 9 & 12.24 & 8 & 10.04 & 9 & 12.16 & 6 & 9.64 & 8 & 10.90 & 7 \\
\hline $\begin{array}{c}\text { Resource } \\
\text { Inadequacy (RIN) }\end{array}$ & 7.60 & 10 & 12.38 & 7 & 9.99 & 10 & 11.34 & 8 & 9.68 & 7 & 10.51 & 8 \\
\hline
\end{tabular}

ences of 5 stressors, namely Self Role Distance (SRD), Role Overload (RO), Personal Inadequacy (PI), Role Erosion (RE), and Role Stagnation (RS), were prominent among the public sector managers. Similarly, the relative weightage of stressors, namely Self Role Distance (SRD), Role Overload (RO), Role Expectation Conflict (REC), Personal Inadequacy (PI), and Role Erosion (RE), were prominent among private sector managers. Significant differences in job-related stress pertaining to the managers in both public and private sector were identified. Results indicated that the influence of Self Role Distance (SRD) and Role Overload (RO) were the most significant among both the public and private sector managers. 
The present findings about the influence of significant stressor variables of managers of both (public and private) sector organizations were also supported by research findings of different researchers [83]-[85]. Cuhadar [64] observed significant difference in the level of role conflict and role ambiguity of public sector and private sector managers. Ahsan [65], Sankpal et al. [66], Correa and Ferreira [10], Bano and Jha [67], Christiana M and Mahalakshmi [68] identified differences in job-related stress pertaining to the managers in both public and private sector.

\subsection{Interpretation on ANOVA Results of Organizational Role Stress Scale Scores for Verification of the Hypothesis}

$\mathrm{H}_{1}$ : "Irrespective of rank position in the organizations the nature of perceive Organizational Role Stress test scores of managers in the public sector organizations and that of private sector organizations".

In order to test the significance of the above-mentioned (Table 1 and Table 2) differences between public sector managers and private sector managers (junior and senior ranks) on overall organizational role stress ORS as well as its components (10), the responses of ORS scale scores of four groups (two types of organizations $\mathrm{x}$ two types of groups) were processed for two way ANOVA and presented in the Table 4 below.

Table 4. Mean (M), Mean difference (MD) and F-ratio values for scores of Organizational Role Stress Scale (ORS) variables under different treatment conditions organizational types (Public and Private) and rank position (Junior and Senior) in job of the managers.

\begin{tabular}{|c|c|c|c|c|c|}
\hline \multirow{2}{*}{$\begin{array}{c}\text { Components of } \\
\text { Organizational } \\
\text { Role Stress Scale. }\end{array}$} & \multicolumn{2}{|c|}{$\begin{array}{l}\text { Mean Values and Mean Difference in ORS } \\
\text { Scores for Sources of Variation between Managers }\end{array}$} & \multicolumn{3}{|c|}{ F-Ratio Values for Sources of Variation } \\
\hline & $\begin{array}{c}\text { Two Kinds } \\
\text { of Organizations } \\
\text { (Public and Private) }\end{array}$ & $\begin{array}{l}\text { Two Rank Condition } \\
\text { (Junior and Senior) }\end{array}$ & $\begin{array}{l}\text { Within the } \\
\text { Types of } \\
\text { Organizations }\end{array}$ & $\begin{array}{c}\text { Within Both the } \\
\text { Two Rank } \\
\text { of Managers }\end{array}$ & $\begin{array}{l}\text { Due to Interactions of } \\
\text { the Kind of Organization } \\
\text { and Ranks Positions. }\end{array}$ \\
\hline $\begin{array}{l}\text { Composite } \\
\text { Organizational Role } \\
\text { Stress scores }\end{array}$ & $\begin{array}{c}\text { Pub Org-M-121.34 } \\
\text { Pvt Org-M-123.62 } \\
\text { MD-1.72 }\end{array}$ & $\begin{array}{l}\text { Junior-120.85 } \\
\text { Senior-122.73 } \\
\text { MD-1.88 }\end{array}$ & 0.08 & 0.74 & $42.14^{*}$ \\
\hline $\begin{array}{c}\text { Inter Role } \\
\text { Distance (IRD) }\end{array}$ & $\begin{array}{l}\text { Pub Org-M-11.25 } \\
\text { Pvt Org-M-10.10 } \\
\text { MD-1.15 }\end{array}$ & $\begin{array}{l}\text { Junior-11.17 } \\
\text { Senior-10.21 } \\
\text { MD-0.96 }\end{array}$ & 3.17 & 2.32 & $4.01^{*}$ \\
\hline Role Stagnation (RS) & $\begin{array}{l}\text { Pub Org-M-11.80 } \\
\text { Pvt Org-M-12.02 } \\
\text { MD-0.22 }\end{array}$ & $\begin{array}{l}\text { Junior-12.39 } \\
\text { Senior-11.43 } \\
\text { MD.96 }\end{array}$ & 0.23 & $4.42^{*}$ & 1.29 \\
\hline $\begin{array}{l}\text { Role Expectation } \\
\text { Conflict (REC) }\end{array}$ & $\begin{array}{l}\text { Pub Org-M-11.52 } \\
\text { Pvt Org-M-13.42 } \\
\text { MD-1.90 }\end{array}$ & $\begin{array}{l}\text { Junior-12.55 } \\
\text { Senior-12.39 } \\
\text { MD-0.16 }\end{array}$ & $13.09^{*}$ & 0.09 & 0.05 \\
\hline Role Erosion (RE) & $\begin{array}{l}\text { Pub Org-M-12.15 } \\
\text { Pvt Org-M-12.67 } \\
\text { MD-0.52 }\end{array}$ & $\begin{array}{l}\text { Junior-12.31 } \\
\text { Senior-12.51 } \\
\text { MD-0.20 }\end{array}$ & 2.02 & 0.08 & $7.95^{*}$ \\
\hline Role Overload (RO) & $\begin{array}{l}\text { Pub Org-M-15.19 } \\
\text { Pvt Org-M-16.31 } \\
\text { MD-1.12 }\end{array}$ & $\begin{array}{l}\text { Junior-16.20 } \\
\text { Senior-15.30 } \\
\text { MD-0.90 }\end{array}$ & $6.62^{*}$ & $10.25^{*}$ & $18.88^{*}$ \\
\hline Role Isolation (RI) & $\begin{array}{l}\text { Pub Org-M-10.95 } \\
\text { Pvt Org-M-10.15 } \\
\text { MD-0.85 }\end{array}$ & $\begin{array}{c}\text { Junior-10.26 } \\
\text { Senior-10.84 } \\
\text { MD-0.58 }\end{array}$ & 2.82 & 1.48 & $36.52^{*}$ \\
\hline $\begin{array}{c}\text { Personal } \\
\text { Inadequacy (PI) }\end{array}$ & $\begin{array}{l}\text { Pub Org-M-11.13 } \\
\text { Pvt Org-M-12.73 } \\
\text { M D-1.60 }\end{array}$ & $\begin{array}{c}\text { Junior-11.39 } \\
\text { Senior-12.47 } \\
\text { M D-1.08 }\end{array}$ & $9.33^{*}$ & $4.25^{*}$ & $8.64^{*}$ \\
\hline $\begin{array}{c}\text { Self Role } \\
\text { Distance (SRD) }\end{array}$ & $\begin{array}{l}\text { Pub Org-M-15.42 } \\
\text { Pvt Org-M-16.62 } \\
\text { MD-1.20 }\end{array}$ & $\begin{array}{c}\text { Junior-16.30 } \\
\text { Senior-15.74 } \\
\text { MD-0.56 }\end{array}$ & 1.80 & $8.30^{*}$ & $13.33^{*}$ \\
\hline Role Ambiguity (RA) & $\begin{array}{l}\text { Pub Org-M-10.04 } \\
\text { Pvt Org-M-10.90 } \\
\text { MD-0.97 }\end{array}$ & $\begin{array}{c}\text { Junior-10.11 } \\
\text { Senior-10.94 } \\
\text { MD-0.93 }\end{array}$ & $3.83^{*}$ & 2.80 & $51.93^{*}$ \\
\hline $\begin{array}{c}\text { Resource } \\
\text { Inadequacy (RIN) }\end{array}$ & $\begin{array}{l}\text { Pub Org-M-10.51 } \\
\text { Pvt Org-M-9.99 } \\
\text { MD-0.52 }\end{array}$ & $\begin{array}{c}\text { Junior-9.47 } \\
\text { Senior-11.03 } \\
\text { MD-1.56 }\end{array}$ & 1.11 & $9.95^{*}$ & $42.41^{*}$ \\
\hline
\end{tabular}

NB: *Indicates the "F” value is significant at 0.05 level. 
Mean and F-ratio values (Table 4) indicate that the overall loading of organizational role stressors of four groups were moderately high. But insignificant F-value (0.08 and 0.74$)$ indicated that there was no significant difference between the groups of managers of modernized public sector organizations and that of private sector organizations with respect to level of overall loading of organizational role stress. Besides, both junior and senior managers revealed their uniformity with respect to overall stress. Of course such trends were also affected due to the interaction of kinds of organization (public and private) of managers.

With uniform loading of pressure of overall role stress both the groups of managers (private sector and public sector) exhibited their specificity in terms of the profile of four (4) components of the organizational role stress scale scores. Mean and F-values highlighted that the strength of influence of components role expectation conflict (M-13.42, F-13.09), role overload (M-16.31, F-6.62), role ambiguity (M-10.90, F-3.83) and personal inadequacy (M-12.73, F-9.33) were significantly higher among managers of private sector organizations than that of public sector organizations. Again the managers of private sector organizations had exhibited significantly different profiles of components of organizational role stress ORS and such trends of differences in the nature of three components role overload, personal inadequacy and role ambiguity (RO, PI and RA) between two groups of managers were also affected due to interaction of rank positions of (senior and junior) of managers.

This means that "Irrespective of rank position in the organizations the nature of perceived Organizational Role Stress test scores of managers in the public sector organizations and that of private sector organizations revealed dissimilarities".

The present study findings of difference between the two groups of managers in terms of components of organizational role stress were corroborated by many studies [85] [86]. Several other studies identified differences in job-related stress among the managers in both public and private sector [10] [64]-[68].

The study further highlighted that irrespective of the type of organization, (public and private) the junior level managers indicated that the strength of influence of stress originating components, Role Overload (M-16.31, F-10.25), due to loading of time urgency, Role Stagnation (M-12.39, F-4.422) feeling of being stuck in the same habitual role without any opportunities for career advancement, and Self Role Distance (M-16.62, F-8.307), conflict arising out of the self-concept and expectations from the role etc. were significantly higher than the seniors. The senior level managers at the same time had projected that the pressure from feeling of Personal Inadequacy (M-12.47, F-4.25), to cope with the innovative changes and challenges of (technology and business process) both within and outside organizations and Resource Inadequacy (M-11.03, F-9.95), in terms of (human, financial and technological) resources for the performance expected for their role in organization were significantly more than that of the junior managers.

One reason behind such differences between junior and senior managers on the nature of stress generating factors personal inadequacy and resource inadequacy (PI and RIN) may be explained in terms of the supplied background information of the managers. An objective analysis indicated that senior managers expressed that they have had relatively lesser exposure to training and management of coping strategies as compared to junior managers, which may be the major cause of their personal inadequacy and lack of competency of handling and utilizing resources adequately for network management to cope with innovative situation and challenges of contingent organization. The junior managers were capable of handling these situations to their benefit as a motivating agent. Srivastava [87] also corroborated and argued that the managers who were able to handle stress in a positive manner were more effective as compared to those who treat stress as a barrier. Chauhan \& Chauhan [82] suggested that it was one's perception, i.e. cognitive interpretation, which decided whether it was positive or negative and how to manage it. Others [75] [76] established age as a personal characteristics while Saravanan and Lawrence [77] identified number of dependents and salary, Fried et al. [78] indicated job performance, Shahu and Gole [47] found lower performance and Anton [79] identified role ambiguity as stressors. Furthermore, the sector which the organization belongs to can also be one of the determinants of role stress for employees as the present study showed [66] [80].

\section{Conclusions}

In the wake of substantial increase in the scale, pace and complexity of business activities worldwide the contemporary horizon of work organizations has changed considerably over the past several decades in economically advanced societies, as well as in the developing societies, due to mushrooming growth of opportunities, expectations, competitive employment situation, new types of job responsibilities, avenues of management practices, etc. Under these circumstances of changing process significant, theoretical and empirical observations had focused on 
that some of the sources and outcomes of occupation specific stress experiences were affected by the potential influences of different types of situation and person related variables in job situations.

The nature and distribution of Organizational Role Stress Scale Scores revealed dissimilarities among the four sample groups. The trend of moderate level of organizational role stress was the general characteristic feature of the managers. Some components for organizational role stress in organization showed reportable variation with rank position (senior/junior) of the managers.

As global competition has increased, managers in organizations have been forced to cope with new conditions of techno-social challenges, which are indirectly influencing and are influenced by the level of occupational stressof the managers. Such occupational stress can influence health, level of wellbeing and quality of performance of the managers on the one hand and organizational achievement status and development on the other hand.

Abaft globalization there has been a substantial increase in the scale, pace and complexity of business activity worldwide spawning widespread incidence of stress in life and work as an inevitable outcome. This has significant bearing on the organizational learning process as it requires explorations into newer and non-conventional sources and methods of learning that help develop multiple levels of managerial competence which is necessary for dealing with turbulence, uncertainty and the resulting stress.

Human capital is an organization's greatest asset, without them everyday functions could not be completed. Humans and the potential they possess drive an organization and the community. Today's organizations are continuously changing. Organizational change impacts not only the business but also its employees as well as the community in which they live. In order to maximize organizational effectiveness, human potential—individuals' capabilities, time, and talents-must be managed.

\section{References}

[1] Pareek, U. (1983) Organizational Role Stress Scale. Manual, Navina Pub., Ahmedabad.

[2] Kahn, R.L., Wolfe, D.M., Quinn, R.P., Snoek, J.D. and Rosenthal, R.A. (1964) Organizational Stress: Studies in Role Conflict and Ambiguity. Wiley, New York.

[3] Srivastava, A.K. (2007) Stress in Organisational Roles: Individual and Organisational Implications. Icfaian Journal of Management Research, 6, 64-74.

[4] Fisher, C. and Gitelson, R. (1983) A Meta-Analysis of the Correlates of Role Conflict and Role Ambiguity. Journal of Applied Psychology, 68, 320-333. http://dx.doi.org/10.1037/0021-9010.68.2.320

[5] Olpin, M. and Hesson, M. (2010) Stress Management for Life: A Research-Based Experiential Approach. 2nd Edition, Wardsworth/Cengage Learning, Belmont.

[6] Pestonjee, D.M. (1992) Stress and Coping: The Indian Experience. Sage Publications.

[7] Schwarzer, R. (2009) Stress and Coping Resources: Theory and Review. Freie University. Berlin. http://web.fuberlin.de/gesund/publicat/ehps_cd/health/stress.htm

[8] Michie, S. (2002) Causes and Management of Stress at Work. Occupational \& Environmental Medicine, 59, 67-72. http://dx.doi.org/10.1136/oem.59.1.67

[9] Bateman, G. (2009) Employee Perceptions of Co-Worker Support and Its Effect on Job Satisfaction, Work Stress and Intention to Quit. Unpublished Dissertation, University of Canterbury. Cited in Khanna, S. (2015) Organisational Role Stress (ORS) and Life Satisfaction among Female Doctors. International Conference on Technology and Business Management, Emirates, 23-25 March 2015, 601-606.

[10] Correa, A.P. and Ferreira, M.C. (2011) The Impact of Environmental Stressors and Types of Work Contract on Occupational Stress. The Spanish Journal of Psychology, 14, 251-262. http://dx.doi.org/10.5209/rev_SJOP.2011.v14.n1.22

[11] Aasland, O.G. and Forde, R. (2005) Impact of Feeling Responsible for Adverse Events on Doctors' Personal and Professional Lives: The Importance of Being Open to Criticism from Colleagues. BMJ Quality \& Safety, 14, 13-17. http://dx.doi.org/10.1136/qshc.2002.003657

[12] Mukherjee, S.B. and Ray, A. (2009) Innovative Work Behaviour of Managers: Implications Regarding Stressful Challenges of Modernized Public- and Private-Sector Organizations. Industrial Psychiatry Journal, 18, 101-107.

[13] Beehr, T.A. and Franz, T. (1987) The Current Debate about the Meaning of Job Stress. In: Ivancevich, J.M. and Ganster, D.C., Eds., Job Stress: From Theory of Suggestion, Haworth Press, New York, 5-18.

[14] Beehr, T.A. and McGrath, J.E. (1992) Social Support Occupational Stress and Anxiety. Anxiety, Stress and Coping, 5, 7-19. http://dx.doi.org/10.1080/10615809208250484 
[15] Wallgreen, L.G. and Hanse, J.J. (2007) Job Characteristics, Motivators and Stress among Information Technology Consultants: A Structural Equation Modeling Approach. International Journal of Industrial Ergonomics, 37, 51-59. http://dx.doi.org/10.1016/j.ergon.2006.10.005

[16] Dupre, K.E. and Day, A.L. (2007) The Effects of Supportive Management and Job Quality on the Turnover Intentions and Health of Military Personnel. Human Resource Management, 46, 185-201. http://dx.doi.org/10.1002/hrm.20156

[17] Kagan, J. (1972) The Psychologists. Oxford University Press, Oxford.

[18] Widmer, C. (1993) Role Conflict, Role Ambiguity, and Role Overload on Boards of Directors of Non-Profit Human Service Organizations. Non-Profit and Voluntary Sector Quarterly, 22, 339-356. http://dx.doi.org/10.1177/0899764093224006

[19] Yousef, D.A. (2000) The Interactive Effects of Role Conflict and Role Ambiguity on Job Satisfaction and Attitudes toward Organizational Change: A Moderated Multiple Regression Approach. International Journal of Stress Management, 7, 289-303. http://dx.doi.org/10.1023/A:1009593913606

[20] Tubre, T.C. and Collins, J.M. (2000) A Meta-Analysis of the Relationships between Role Ambiguity, Role Conflict, and Job Performance. Journal of Management, 26, 155-169. http://dx.doi.org/10.1177/014920630002600104

[21] Mohr, A.T. and Puck, J.F. (2007) Role Conflict, General Manager Job Satisfaction and Stress and the Performance of IJVs. European Management Journal, 25, 25-35. http://dx.doi.org/10.1016/j.emj.2006.11.003

[22] Wu, L. and Norman, I.J. (2006) An Investigation of Job Satisfaction, Organizational Commitment and Role Conflict and Ambiguity in a Sample of Chinese Undergraduate Nursing Students. Nurse Education Today, 26, 304-314. http://dx.doi.org/10.1016/j.nedt.2005.10.011

[23] Katz, D. and Kahn, R.L. (1966) The Social Psychology of Organizations. John Wiley and Sons, New York.

[24] Pareek, U. (1993) Making Organizational Roles Effective. Tata McGraw Hill, New Delhi.

[25] Jena, P. and Pradhan, S. (2011) Impact of Organizational Role Stress among Library Professionals of Odisha: A Study. PEARL-A Journal of Library and Information Science, 5, 1-8.

[26] Fernandes, C.F.V., Kumar, S. and Mekoth, N. (2009) Gender Differences in Stress among Bank Officers of Private and Public Sectors. The ICFAI University Journal of Organizational Behavior, 8, 63-69.

[27] Dasgupta, H. and Kumar, S. (2009) Role Stress among Doctors Working in a Government Hospital in Shimla (India). European Journal of Social Sciences, 9, 356-370.

[28] Aziz, M. (2003) Organizational Role Stress among Indian Information Technology Professionals. Asian-Pacific Newsletter on Occupational Health and Safety, 10, 31-39.

[29] Cox, T. and Griffiths, A. (2010) Work Related Stress: A Theoretical Perspective. In: Leka, S. and Houdmont, J., Eds., Occupational Health Psychology, Wiley-Blackwell, Chichester, 31-56.

[30] Pareek, U. (1976) Inter-Role Exploration. In: Pfeiffer, J.W. and Jones, J.E., Eds., The 1976 Annual Handbook for Group Facilitators, University Associates, San Diego, 211-224.

[31] Pareek, U. (2003) Training Instruments in HRD and OD. Tata McGraw Hill, Bombay.

[32] Mintzberg, H. (1983) Power in and Around Organizations. Prentice-Hall, Upper Saddle River.

[33] Pestonjee, D.M. and Pareek, U. (1997) Studies in Organizational Role Stress and Coping. D. K. Publishers, New Delhi.

[34] Zaltman, G., Duncan, R. and Holbeck, J. (1973) Innovation and Organizations. John Wiley, New York, 45-68.

[35] Lundberg, U. (2000) Workplace Stress. In: Fink, G., Ed., Encyclopedia of Stress, Volume 3, Academic Press, San Diego, 684 .

[36] Abramis, D.J. (1994) Relationship of Job Stressors to Job Performance: Linear or an Inverted-U. Psychological Reports, 75, 547-558. http://dx.doi.org/10.2466/pr0.1994.75.1.547

[37] Ruhaini, I. and Hassim, I.N. (2006) The Prevalence of Occupational Stress among Doctors in Kuala Lumpur Hospital in 1995-1996. Journal of Community Health (Malaysia), 12.

[38] Burke, J.M. (1986) The Relationship between Type-A Behaviour, Role Stress, Job Enrichment and Burnout among College Counselors. Dissertation Abstract International, 46, 3588.

[39] Ahmad, S., James, J. and Ahmad, S. (1991) Organizational Role Stress: A Psychological Study of Middle Managers. Journal of Personality and Clinical Studies, 7, 43-48.

[40] Cox, T. (1978) Stress. MacMillan, London.

[41] Behrman, D.N. and Perreault, W.D. (1984) A Role Stress Model of the Performance and Satisfaction of Industrial Salespersons. Journal of Marketing, 48, 9-21.

[42] Jex, S.M. (1998) Stress and Job Performance. Sage Publications, London. 
[43] Glazer, S. and Beehr, T.A. (2005) Consistency of Implications of Three Role Stressors across Four Countries. Journal of Organizational Behaviour, 26, 467-487. http://dx.doi.org/10.1002/job.326

[44] Bettencourt, L.A. and Brown, S.W. (2003) Role Stressors and Customer Oriented Boundary-Spanning Behaviours in Service Organizations. Journal of the Academy of Marketing Science, 31, 394-408. http://dx.doi.org/10.1177/0092070303255636

[45] Beehr, T.A., Walsh, J.T. and Taber, T.D. (1976) Relationship of Stress to Individually and Organizationally Valued States: Higher Order Needs as a Moderator. Journal of Applied Psychology, 61, 41-47. http://dx.doi.org/10.1037/0021-9010.61.1.41

[46] Narayanan, L., Menon, S. and Spector, P.E. (1999) Stress in the Workplace: A Comparison of Gender and Occupation. Journal of Organizational Behavior, 20, 63-73. http://dx.doi.org/10.1002/(SICI)1099-1379(199901)20:1<63::AID-JOB873>3.0.CO;2-J

[47] Shahu, R. and Gole, S.V. (2008) Effect of Job Stress and Job Satisfaction on Performance: An Empirical Study. AIMS International Journal of Management, 2, 237-246.

[48] Knight, D.K., Kim, H.-J. and Crutsinger, C. (2007) Examining the Effects of Role Stress on Customer Orientation and Job Performance of Retail Salespeople. International Journal of Retail and Distribution Management, 35, 381-391. http://dx.doi.org/10.1108/09590550710743735

[49] Pestonjee, D.M. and Singh, U.B. (1982) Job Satisfaction as a Function of Role Stress, Locus of Control, Participation and Organizational Climate in an Electric Supply Company. Manuscript, Indian Institute of Management, Ahmedabad.

[50] Pestonjee, D.M. and Singh, U.B. (1983) EDP Managers: An Organizational Behaviour Study. Manuscript, Indian Institute of Management, Ahmedabad.

[51] Kemery, E.R., Bedeian, A.G., Mossholder, K.W. and Touliatos, J. (1985) Outcomes of Role Stress: A Multi-Sample Constructive Replication. Academy of Management Journal, 28, 363-375. http://dx.doi.org/10.2307/256206

[52] Montgomery, M.R. (2012) Does an Absence of Managerial Communication Negatively Influence Job Satisfaction? A Quantitative Examination of the Correlation between Job Satisfaction and Role Conflict and Role Ambiguity among High-Tech Employees. CAPELLA University, Pub No. 3461658.

[53] Calisir, F. and Gumussoy, C.A. (2011) Factors Affecting Intention to Quit among IT Professionals in Turkey. Personnel Review, 40, 514-533. http://dx.doi.org/10.1108/00483481111133363

[54] Beehr, T.A. (1995) Psychological Stress in the Workplace. Routledge, London.

[55] Beehr, T.A. and Glazer, S. (2005) Organizational Role Stress. In: Barling, J., Kelloway, E.K. and Frone, M.R., Eds., Handbook of Work Stress, Sage, Thousand Oaks, 7-33. http://dx.doi.org/10.4135/9781412975995.n2

[56] Jackson, S. and Schuler, R. (1985) A Meta-Analysis and Conceptual Critique of Research on Role Ambiguity and Role Conflict in Work Setting. Organizational Behaviour and Human Decision Processes, 36, 16-78. http://dx.doi.org/10.1016/0749-5978(85)90020-2

[57] Linzer, M., Gerrity, M., Douglas, J.A. and Mckurry, J.E. (2002) Physicians Stress: Results from the Physicians Work Life Study. Stress \& Health, 18, 37-42.

[58] Jones, M.D. (2006) Which Is a Better Predictor of Job Performance: Job Satisfaction or Life Satisfaction. Journal of Behaviour and Applied Measurement, 8, 20-42.

[59] Greguras, G.L. and Diefendorff, J.M. (2010) Why Does Proactive Personality Predict Employee Life Satisfaction and Work Behaviour? A Field Investigation of the Mediating Role of the Self-Concordance Model. Personnel Psychology, 63, 539-560. http://dx.doi.org/10.1111/j.1744-6570.2010.01180.x

[60] Boles, J.S., Wood, J.A. and Johnson, J. (2003) Interrelationships of Role Conflict, Role Ambiguity and Work-Family Conflict with Different Facets of Job Satisfaction and the Moderating Effects of Gender. Journal of Personal Selling \& Sales Management, 23, 99-113.

[61] LeRouge, C., Nelson, A. and Blanton, J.E. (2006) The Impact of Role Stress Fit and Self-Esteem on the Job Attitudes of IT Professionals. Information \& Management, 43, 928-938. http://dx.doi.org/10.1016/j.im.2006.08.011

[62] Mulki, J.P., Lassk, F.G. and Jaramillo, F. (2008) The Effect of Self-Efficacy on Sales Person Work over Load and Pay Satisfaction. Journal of Personal Selling \& Sales Management, 28, 285-297.

[63] Verma, S. (2008) Stress Questionnaire for Lawyers: Implications of Burnout and Psychosocial Stressors for the Job Satisfaction among Male and Female Lawyers. Unpublished Master's Thesis, Himachal Pradesh University, Shimla.

[64] Cuhadar, M.T. (2008) The Sectoral Analyses of Role Conflict and Role Ambiguity with Job Satisfaction and Organisational Commitment: A Study in the East Mediterranean Region. Journal of Global Strategic Management, 2, 108-119.

[65] Ahsan, N., Abdullah, Z., Fie, D.Y.G. and Alam, S.S. (2009) A Study of Job Stress on Job Satisfaction among University Staff in Malaysia: Empirical Study. European Journal of Social Sciences, 8, 121-131. 
[66] Sankpal, S., Negi, P. and Vashishtha, J. (2010) Organisational Role Stress of Employees: Public vs. Private Banks. Indian Journal of Management, 3, 4-16.

[67] Bano, B. and Jha, R.K. (2012) Organizational Role Stress among Public and Private Sector Employees: A Comparative Study. The Lahore Journal of Business, 1, 23-36.

[68] Christiana M, B.V. and Mahalakshmi, V. (2013) Role Stress and Its Impact on Public and Private Sector Managers in Chennai: An Empirical Study. International Journal of Management \& Business Studies, 3, 22-26.

[69] Khanna, S. (2015) Organisational Role Stress (ORS) and Life Satisfaction among Female Doctors. Proceedings of the International Conference on Technology and Business Management, Emirates, 23-25 March 2015, 601-606.

[70] Beehr, T.A. and Newman, J.E. (1978) Job Stress, Employee Health and Organizational Effectiveness: A Facet Analysis, Model and Literature Review. Personnel Psychology, 31, 665-699. http://dx.doi.org/10.1111/j.1744-6570.1978.tb02118.x

[71] Payne, R. (1988) Individual Differences in the Study of Occupational Stress. In: Cooper, C.L. and Payne, R., Eds., Causes, Coping, and Consequences of Stress at Work Chapter 7, John Wiley and Sons, Chichester.

[72] Swanson, V. and Power, K.G. (1998) Occupational Stress and Family: A Comparison of Male and Female Doctors. Journal of Occupational and Organizational Psychology, 71, 237-260. http://dx.doi.org/10.1111/j.2044-8325.1998.tb00675.x

[73] Tankha, G. (2006) A Comparative Study of Role Stress in Government and Private Hospital Nurses. Journal of Health Management, 8, 11-22. http://dx.doi.org/10.1177/097206340500800102

[74] Masood, R.Z. (2011) Stress Management: A Key to Employee Retention. Management Insight, 7, 100-111.

[75] Clayson, D.E. and Frost, T.F. (1984) Impact of Stress and Locus of Control on the Concept of Self. Psychological Reports, 55, 919-926. http://dx.doi.org/10.2466/pr0.1984.55.3.919

[76] Chandriah, K., Agrawal, M. and Manoharan, N. (2003) Occupational Stress and Job Satisfaction among Managers. Indian Journal of Occupational and Environmental Medicine, 7, 6-11.

[77] Saravanan, P. and Lawrence, M.A. (2007) Occupational Stress among the Librarians of Arts and Science Colleges. Library Progress (International), 27, 51-57.

[78] Fried, Y., Arie, S., Gilboa, S. and Cooper, C.L. (2008) The Mediating Effects of Job Satisfaction and Propensity to Leave on Role Stress-Job Performance Relationships: Combining Meta-Analysis and Structural Equation Modeling. International Journal of Stress Management, 15, 305-328. http://dx.doi.org/10.1037/a0013932

[79] Anton, C. (2009) The Impact of Role Stress on Workers' Behaviour through Job Satisfaction and Organizational Commitment. International Journal of Psychology, 44, 187-194. http://dx.doi.org/10.1080/00207590701700511

[80] Malik, N. (2011) A Study on Occupational Stress Experienced by Private and Public Bank Employees in Quetta City. African Journal of Business Management, 5, 3063-3070.

[81] Pareek, U. (2002) Training Instruments in HRD and OD. Tata McGraw Hill Publishing Ltd., New Delhi.

[82] Chauhan, D. and Chauhan, S.P. (2005) Stress: Can It Be a Motivating Force for Realizing One’s Potential? Indian Journal of Industrial Relations, 40, 410-419.

[83] Dhadda, N. (1990) A Study of the Relationship of Role Stress, Job Involvement and Personality Types in Aviation and Railway Officials. Unpublished Master’s Dissertation, University of Rajasthan, Jaipur.

[84] Singh, A.P. and Singh, B. (1997) Correlates of Psychological Strain and Coping Behaviour. In: Pestonjee, D.M. and Pareek, U., Eds., Studies in Organizational Role Stress and Coping, Rawat Publication, Jaipur, 122-136.

[85] Sharma, T. (1987) Differential Effects of Organizational Climate on Job Satisfaction, Sense of Participation, and Role Stress. Unpublished Ph.D. Thesis, Gujarat University, Ahmedabad.

[86] Mohanty, S. and Mishra, P.K. (1998) Occupational Stress: A Comparative Study of Public \& Private Sector. Social Science International, 14, 29-39.

[87] Srivastava, S. (2009) Locus of Control as a Moderator for Relationship between Organizational Role Stress and Managerial Effectiveness. Vision-The Journal of Business Perspective, 13, 49-61. http://dx.doi.org/10.1177/097226290901300405 